\title{
AN ANALYSIS OF THE GENERAL ENFORCEMENT APPROACHES TO COMBAT MARKET ABUSE (PART 2)*
}

\author{
Howard Chitimira \\ LLB LLM LLD \\ Research Administrative Assistant \\ to the Executive Dean, Faculty of Law \\ Nelson Mandela Metropolitan University \\ Port Elizabeth \\ Vivienne A Lawack \\ BJuris LLB LLM LLD \\ Professor of Law, Executive Dean, Faculty of Law \\ Nelson Mandela Metropolitan University \\ Port Elizabeth
}

\section{SUMMARY}

This article is the second part in a two-part series on general enforcement approaches to combat market abuse. Part 2 analyses the role and use of selected general anti-market abuse approaches in order to increase awareness and enforcement on the part of the relevant stakeholders. To this end, the article provides an evaluation of selected general anti-market abuse-enforcement approaches as well as the significant advantages and disadvantages of such approaches. This is done by discussing anti-market abuse measures that primarily deal with surveillance, detection and investigation, whereas Part 1 examined the anti-market abuse measures that primarily deal with enforcement.

\section{INTRODUCTION}

For the purposes of this article "market abuse" is used as a generic term referring to insider trading and market manipulation. South Africa has market-abuse legislation in place but nonetheless there are no specific regulations and/or sufficient relevant information on the measures or general approaches that are employed to enhance the implementation of such legislation to combat market abuse. The objective of this article is to analyse the role and use of some selected general approaches to combat market abuse in order to increase awareness and enforcement on the part of the 
relevant stakeholders globally. To this end, this second article provides an analysis of anti-market abuse approaches that primarily deal with surveillance, detection and investigation ${ }^{1}$ as well as the significant advantages and disadvantages of such approaches. ${ }^{2}$ Notably, a similar analysis of anti-market abuse measures that primarily deal with enforcement was undertaken in the first article.

\section{ANALYSIS OF ANTI-MARKET ABUSE MEASURES THAT PRIMARILY DEAL WITH SURVEILLANCE, DETECTION AND INVESTIGATION}

\section{The role and use of regulatory bodies to combat market abuse}

A number of regulatory bodies have been established in several countries to enforce securities and other related laws. ${ }^{3}$ In many countries such regulatory bodies are statutorily empowered with relevant powers to take appropriate action on behalf of the affected persons and to punish those who violate market-abuse laws. Conspicuously, these regulatory bodies are usually empowered to institute civil and administrative measures against the marketabuse offenders. ${ }^{4}$ This could imply, depending on a country, that such regulatory bodies do not have the exclusive authority to institute their own criminal proceedings against the market-abuse offenders. ${ }^{5}$

* This article was influenced in part by Chitimira's studies towards his LLD degree. His thesis is entitled A Comparative Analysis of the Enforcement of Market Abuse Provisions (2011), Nelson Mandela Metropolitan University (see Chapter One). In this regard, he wishes to acknowledge the expert help and input of Professor VA Lawack.

1 It should be noted that the analysis does not exclusively focus on the anti-market abuse enforcement approaches that are employed in a particular specific jurisdiction alone. The focus will be on the anti-market abuse-enforcement approaches that are commonly employed in different jurisdictions. Where necessary, consideration will also be given to pertinent theoretical arguments regarding the enforcement approaches that may have been used to curb market abuse more successfully than others in such jurisdictions.

2 Berkahn Regulatory and Enabling Approaches to Corporate Law Enforcement: Patterns of Litigation 1986-2002 and The Effect of Recent Reforms in New Zealand, Australia and the United Kingdom (2006) 10-18, for a related discussion on the merits and demerits of public and private enforcement of securities laws.

3 South Africa, the United Kingdom, United States of America, Australia and other European Union member countries have specific regulatory bodies that are authorized to enforce securities laws and to punish offenders. For more information on the role of such regulators, see Duan "The Ongoing Battle Against Insider Trading: A Comparison of Chinese and US Law and Comments on how China Should Improve its Insider Trading Law Enforcement" 2009 Duquesne Business LJ 129 149; Coffee "Harmonization of Enforcement" 2009 Columbia University Law School Memorandum Paper 03/09/09 8-10; and Atkins and Bondi "Evaluating the Mission: A Critical Review of the History and Evolution of the SEC Enforcement Program" 2008 Fordham Journal of Corporate and Financial Law 367387.

4 Tompkins "Opportunity Knocks, but the SEC Answers: Examining the Manipulation of Stock Options through the Spring-Loading Grants and Rule 10b-5" 2008 Journal of Law and Policy 413 415-458; Duan 2009 Duquesne Business LJ 149, for a discussion on the role of the China Securities Regulatory Committee; Russen Financial Services Authorisation, Supervision, and Enforcement: A Litigator's Guide (2006) 135-137, for more analysis on the role of the Securities and Exchange Commission; and Barnard "Evolutionary Enforcement at the Securities and Exchange Commission" 2010 University of Pittsburg LR 403.

5 Liebman and Milhaupt "Reputational Sanctions in China's Securities Market" 2007-2008 Columbia $L R 1$ 18. Also see generally Grabosky and Braithwaite (eds) Business Regulation 
The main advantage of relying on independent regulatory bodies is, in our opinion, the high probability of obtaining more settlements and the provision of compensation to the victims of market-abuse activities. Another advantage of using independent regulatory bodies is that they are, in some instances, well-resourced and they derive their operational capital from the proceeds of, or money recovered from the market-abuse offenders. ${ }^{6}$ However, the main disadvantage of relying on independent regulatory bodies is their bureaucracy as regards the victims' application and claiming of marketabuse compensatory damages through such bodies in different countries. In relation to this, the use of regulatory bodies has drawn mixed reactions from different scholars. Britton and Bohannon submit that regulatory bodies are essentially important in the general enforcement of the securities laws. ${ }^{7}$ They proceed nonetheless to say that there is a danger of some regulatory bodies becoming "overzealous in their role as the enforcers of securities laws to the detriment of investors". Importantly, Britton and Bohannon theoretically raise a question whether or not the regulatory bodies are solely capable of effectively enforcing the securities laws. ${ }^{9}$ However, this is an empirical question which in most instances does not always readily lead to a definite and satisfactory answer.

Other commentators have criticized and described the role of regulatory bodies in some countries as only "bark and no bite" dogs. ${ }^{10}$ Additionally, Duan criticizes the poor enforcement tactics employed by the relevant regulatory bodies in China. ${ }^{11}$ Duan further asserts that incompetent regulatory bodies do not serve the public interest in deterring market-abuse conduct like insider trading. ${ }^{12}$

On the contrary Barnes, $\mathrm{Hu}$ and Shi acknowledge that regulatory bodies play a big role in the enforcement of securities laws in many countries. ${ }^{13}$

and Australia's Future (1992) 9-67 and 97-177; and Swanson "Insider Trading Madness: Rule 10b5-1 and the Death of Scienter" 2003-2004 Kansas LR 148 168-179, for related comments.

6 Van Deventer "Harnassing Administrative Law in Encouraging Compliance" 2009 FSB Bulletin 3 3-4; see further Benny "Insider Trading Laws and Stock Markets Around the World: An Empirical Contribution to the Theoretical Law and Economics Debate" 2006 John M Olin Center for Law and Economics, University of Michigan Law School Paper 04-004 482.

7 Britton and Bohannon '"PERP' Walk or Cake Walk? A Study of the SEC's Enforcement of the Securities Laws Through Agreed Settlements" 2005 Houston Business and Tax LJ 244 247.

8 Ibid.

9 Ibid.

10 See Gray "Financial Services and Markets Tribunal Orders that Costs of Successful Challenge to Enforcement Action for Market Abuse be Paid by FSA" 2007 Journal of Financial Regulation and Compliance 217 218-220, where the role of the Financial Services Authority was criticized for taking unjustifiable actions against the accused market-abuse offenders in some instances; and see further Benny 2006 John M Olin Center for Law and Economics, University of Michigan Law School Paper 04-004 4-82.

11 See Duan 2009 Duquesne Business LJ 148, where China Securities Regulatory Committee's insider-trading enforcement record was described as being "far from satisfactory".

12 Duan 2009 Duquesne Business LJ 132.

13 See further Barnes "Insider Dealing and Market Abuse: The UK's Record on Enforcement" 2010 1-19 http://mpra.ub.uni-muenchen.de/25585/1/insiderdealing2010.pdf (accessed 2010 10-17); and Hu and Shi "Directors' Liability for False Statements in the Information 
They assert that regulatory bodies provide a vital role in bridging gaps between legislation and filling in loop holes in the regulatory systems of the securities markets in several countries. ${ }^{14}$ Similarly, Lynch states that private enforcement of securities laws by regulatory bodies promotes efficiency and avoids governmental bureaucracies associated with the criminal enforcement of such laws by authorized government departments. ${ }^{15}$ Independent regulatory bodies are not controlled by governments and this may in a way enable them to be more efficient and free from corruption and underperformance. ${ }^{16}$ This view could have been merely based on the fact that regulatory bodies are sometimes flexible because they are usually given wider discretionary powers to enforce securities laws in some countries.

\section{The role and use of surveillance and detection measures to combat market abuse}

Detection and surveillance measures are used by regulatory bodies and other authorized securities exchanges to prevent and control market-abuse activity in other countries. ${ }^{17}$ Market-abuse activity is extremely difficult to detect. ${ }^{18}$ In light of this, electronic market surveillance techniques are used to detect the occurrence of illicit trading practices in the financial markets in several countries. ${ }^{19}$ In many countries, highly sophisticated and computerized surveillance systems are used to monitor market activity and trading patterns in order to detect insider trading and other market abuse practices. ${ }^{20}$ Such practices are usually detected by unusual or abnormal price movements through some programmed alerts which, depending on each country, are sent to the regulatory bodies for further investigations.

Disclosure of Listed Companies in China" 2008 Journal of the Australasian Law Teachers Association 6771.

14 Hu and Shi 2008 Journal of the Australasian Law Teachers Association 71.

15 Lynch "The Role of Criminal Law in Policing Corporate Misconduct" 1997 Law and Contemporary Problems 2334.

16 MacMillan and Woodruff "Private Order under Dysfunctional Public Order" 2000 Michigan LR 24212430.

17 Rose "Reforming Securities Litigation Reform: Restructuring the Relationship between Public and Private Enforcement of Rule 10b-5" 2008 Columbia LR 1301 1304-1364, argues that the Securities and Exchange Commission concentrates more on detection because it has advanced investigation resources.

18 Lyon and Du Plessis The Law of Insider Trading in Australia (2005) 163.

19 Patrick "Tech Boom Pressures ASX" 1999 Australian Financial Review 1 39; see further Prentice "The Internet and Its Challenges for the Future of Insider Trading Regulation" 1999 Harvard Journal of Law and Technology 265 332-356; Benny 2006 John M Olin Center for Law and Economics, University of Michigan Law School Paper 04-004 4-82; and Seyhun "The Effectiveness of the Insider-Trading Sanctions" 1992 Journal of Law and Economics $149150-155$, for related comments on the measures used to increase the effectiveness of insider-trading laws in the United States of America.

20 Benny 2006 John M Olin Center for Law and Economics, University of Michigan Law School Paper 04-004 4-82; see further Coffee "The Dynamics of Capital Market Governance: Evaluating the Conflicting and Conflating Roles of Compliance, Regulation, Ethics and Accountability" 2007 ESRC/GOVNET Workshop Paper, Australian National University 2-75.

21 Lyon and Du Plessis The Law of Insider Trading in Australia 163, explains the Surveillance of Market Activity and Stock Exchange Automated Training Systems that are used in Australia to monitor all real-time trading information and to indicate any abnormal tradingprice movements which could have been caused by market abuse activities; see further Engelen "Criminal Behaviour: a Real Option Approach with an Application to Restricting 
The main advantage of using surveillance and detection measures is that they can easily and timeously detect the occurrence of illicit trading activities in the financial markets. Lyon echoes these sentiments and adds that surveillance and detection measures can detect the indicia of insider-trading activity readily enough at market level, if they are operated by the persons with the relevant expertise. ${ }^{22}$

Lynch purports that the coordination of regulatory bodies' persons with the relevant expertise is critically vital for the purposes of deterrence and detection of all corporate wrongdoing. ${ }^{23}$ In relation to this, some regulatory agencies have specific divisions that deal with, and operates proprietary scan programmes, telephonic digital data recording and other relevant measures to detect possible market-abuse practices. ${ }^{24}$ Nonetheless, procurement of sufficient and relevant equipment required for market surveillance has been a challenge in some jurisdictions. ${ }^{25}$ Shen comments that the China Securities Regulatory Committee has insufficient resources, especially for the purposes of timely investigation, surveillance and detection of fraud and other securities violations. ${ }^{26}$

Carvajal and Elliot state further that detection and surveillance of corporate crime is a "resource-intensive exercise". ${ }^{27}$ They also argue that fully effective enforcement measures for investigation, detection and surveillance programmes require skilled persons to run them. ${ }^{28}$ According to Carvajal and Elliot, countries like Brazil, Chile and Portugal were reported to have adopted and established separate enforcement divisions within their relevant regulatory bodies to enforce securities laws actively. ${ }^{29}$ Nevertheless, Carvajal and Elliot did not give a clear indication on whether or not such enforcement divisions were able to combat market-abuse practices effectively.

In the same light, Gething argues that the greatest obstacle associated with detection and surveillance measures is the difficulty in promptly

Illegal Insider Trading" 2004 European Journal of Law and Economics 329 335-352; Gething "Insider Trading Enforcement: Where are We Now and Where do We Go From Here?"1998 Company and Securities LJ 607 618; and Lynch "Part V: SEC Enforcement Trends 2009Insider Trading" 2009 1-2 http://www.secactions.com/?p=960 (accessed 2009-05-28).

22 Lyon and Du Plessis The Law of Insider Trading in Australia 163-164.

23 Lynch 1997 Law and Contemporary Problems 53.

24 Rashkover and Kleiman "SEC Enforcement and Examinations Concerning Hedge Funds" 2007-2008 New York Law School LR 600 619-620.

25 Liebman and Milhaupt 2007-2008 Columbia LR 12-15, for any analysis on China's Shangai and Shen Zhen stock exchange's regulatory measures against market abuse and other criticisms of the China Securities Regulatory Committee's shortcomings in detecting and combating insider trading; Shen "A Comparative Study of Insider Trading Regulation Enforcement in the US and China" 2008 Journal of Business and Securities Law 42 53-63, for a similar comparative analysis of the Securities and Exchange Commission and China Securities Regulatory Committee's detection and enforcement record.

26 Shen 2008 Journal of Business and Securities Law 58.

27 Carvajal and Elliot "The Challenge of Enforcement in Securities Markets: Mission Impossible?" 2009 International Monetary Fund Working Paper WP/09/168 26.

28 Carvajal and Elliot 2009 International Monetary Fund Working Paper WP/09/168 26-27.

29 Carvajal and Elliot 2009 International Monetary Fund Working Paper WP/09/168 27 and 30 , who nonetheless maintain that some regulators lack sufficient resources for the effective surveillance of market abuse and other security violations; and also see Jackson and Roe "Public and Private Enforcement of Securities: Resource-Based Evidence" 200810 http://ssrn.com/abstract=1000086 (accessed 2010-10-13). 
detecting the identity of the offenders in question and thereafter proving their causal link or connection to a particular detected market-abuse violation. ${ }^{30}$

Notwithstanding the remarks above, the authors contend that detection and surveillance measures form the integral part of the market-abuse enforcement tactics used by regulatory bodies globally. In this regard, the authors submit that regulatory bodies must be encouraged to use the appropriate detection and surveillance measures that are operated by the persons with the relevant expertise to combat-market-abuse activity cautiously and consistently in the global financial markets.

\section{The role and use of investigation- and information- gathering measures to combat market abuse}

Investigation- and information-gathering is another tool that is universally used to prevent security violations by some dishonest persons. ${ }^{31}$ Various methods are used by regulatory bodies in different countries to get information relating to market-abuse violations and to isolate the culprits involved. ${ }^{32}$ A preliminary investigation into any alleged violation is usually conducted by the independent regulatory bodies in some countries like South Africa and the United States of America. ${ }^{33}$ When such investigation is concluded and information on market-abuse violations is found, the independent regulatory bodies will, in most instances, refer the matter to the prosecuting authorities for further investigations and/or prosecution. ${ }^{34}$

In some countries, market-abuse investigations by independent regulators will only commence after a tip-off or a referral has been obtained either from members of the general public or from specific informants. ${ }^{35}$ Only a formal investigation allows the regulatory bodies to have subpoena power to

30 Gething 1998 Company and Securities LJ 618-620; see further Lyon and Du Plessis The Law of Insider Trading in Australia 164; and related analysis by Armson "False Trading and Market Rigging in Australia" 20092 http://www.clta.edu.au/professional/papers/papers /conference2009/ArmsonCLTA09.pdf (accessed 2010-05-10), who argues that marketabuse activities like the making of false or misleading statements are notoriously difficult to detect and to prove the intention or other mental element necessary to secure a criminal conviction.

31 Mtshali "DMA Investigates 14 Insider Trading Cases" 29 November 2007 Daily Dispatch 10.

32 Langevoort "Insider Trading and The Fiduciary Principle: A Post Chiarella Statement" 1982 California $L R 118$, points out the need for companies to disclose price-sensitive information to the markets to curb market-abuse practices like insider trading; Lyon and Du Plessis The Law of Insider Trading in Australia 166, for comments on the measures used in some countries such as immunity provisions and monetary rewards, to encourage people to bona fide disclose any information relating to market-abuse practices.

33 Perez, Cochran and Sousa "Securities Fraud" 2008 American Criminal LR 923 925-934, for a further discussion on the Securities and Exchange Commission's preliminary investigations into securities violations in the United States of America.

34 Perez, Cochran and Sousa 2008 American Criminal LR 925-934, where it was stated that the Securities and Exchange Commission will only publish its market-abuse investigation results formally if it has found formal concrete information on the violations in question; and also see Hazem The Law of Securities Regulation: Handbook Series Student Edition (1985) 247-250, for further discussion on the Securities and Exchange Commission's market-abuse investigations.

35 Shen 2008 Journal of Business and Securities Law 56-57, where it was stated that the Securities and Exchange Commission may receive referrals from the examination staff and its Division of Corporation Finance. 
summon the accused persons for interrogation in some countries like the United States of America and China ${ }^{36}$ Thus, according to Hazem, the subpoena powers are only exercised where regulatory bodies are convinced that there will be "a likelihood of violation". ${ }^{37}$

On-site inspections are further used in some jurisdictions to collect information relating to any suspected market-abuse violations. ${ }^{38}$ In addition to this, other countries use investigation measures like interviews and information-sharing agreements to obtain the relevant information pertaining to market-abuse offences. ${ }^{39}$ Likewise, other countries have empowered specific regulatory bodies to summon any persons accused of committing market-abuse offences for interrogation. ${ }^{40}$ Furthermore, regulatory bodies in some countries are given powers to search and seize any premises or persons suspected of market-abuse violations to procure documents or other material relevant to an ongoing market abuse investigation. ${ }^{41}$ In line with this, Hansen ${ }^{42}$ hails the adoption and use of investigation and information-gathering measures in the European Union member countries as required under the European Union Market Abuse Directive. ${ }^{43}$ According to Hansen, such measures enable the regulatory bodies to prevent promptly any conduct that is contrary to the European Union Market Abuse Directive. ${ }^{44}$ Hansen does not, however, give any detail on whether or not the investigation- and information-gathering measures have been successfully relied upon in the European Union member countries to curb market abuse.

Carvajal and Elliot submit that investigation and information-gathering measures are "time-consuming, requiring long hours of requesting, collecting and analysing any received data on market abuse and/or other securities

${ }^{36}$ Hazem The Law of Securities Regulation 247; and Shen 2008 Journal of Business and Securities Law 56

37 Hazem The Law of Securities Regulation 247.

38 Carvajal and Elliot 2009 International Monetary Fund Working Paper WP/09/168 26-27; and Hansen "MAD in a Hurry: The Swift and Promising Adoption of the EU Market Abuse Directive" 2004 European Business LR 183 220, explaining that on-site inspections are used under the Market Abuse Directive to discourage market-abuse practices in some European Union member countries.

39 Mann, Leder and Jacobs "The Establishment of International Mechanisms for Enforcing Provisional Orders and Final Judgments Arising from Securities Law Violations" 1992 Law and Contemporary Problems 303 305-322, state that information-sharing mechanisms between regulatory bodies have improved the isolation and tracking of illicit conduct by market-abuse offenders, including cross-border market-abuse activities that are executed in other jurisdictions.

40 This is true for inter alia countries like China, South Africa, United States of America and Australia.

41 Hansen 2004 European Business LR 219-220, who posits that European Union member countries have regulatory bodies which have discretional interrogative powers as well as powers to carry out on-site inspections to curb market abuse practices. Also see Easterbrook "Insider Trading, Secret Agents, Evidentiary Privileges and the Production of Information" 1981 Supreme Court Review 309, for related comments on the use of investigation and information gathering measures to prevent insider trading and other securities violations.

42 Hansen 2004 European Business LR 219-220.

${ }^{43}$ See the Directive of the European Parliament and Council of 28 January 2003 on insider dealing and market manipulation (market abuse) 2003/6/EC [2003] OJ L96/16 (hereinafter "the EU Market Abuse Directive").

44 Hansen 2004 European Business LR 220. 
violations". ${ }^{45}$ The authors agree in part with these Carvajal and Elliot's opinions $^{46}$ and they further submit that the regulatory bodies must utilize the investigation- and information-gathering measures effectively by being staffed adequately with the investigators and other persons with a variety of relevant skills and the understanding of the financial markets.

Lyon advocates for the adoption of mandatory continuous disclosure of price-sensitive information, especially among the listed companies to enable the regulatory bodies to make timeous investigations into any suspected market-abuse violations. ${ }^{47}$ The authors submit that Lyon's ${ }^{48}$ proposition seems to be based only on the upholding of the theory of equal access to information among all the market participants in order to discourage market abuse. Likewise, Blair and Ramsay support the use of mandatory disclosure requirements that are enforced by regulatory bodies in order to get all the relevant information so as to prevent market-abuse activities. ${ }^{49}$ They further submit that mandatory disclosure requirements may address the disincentives faced by persons who release price-sensitive inside information which could affect the price of certain securities adversely. ${ }^{50}$ While there might not be any satisfactory justification for the use of investigation- and information-gathering measures, the authors concur with Lyon and Blair and Ramsay that such measures play an important part in the prevention of market-abuse practices. Shen maintains that some countries employ "parallel investigation actions" between criminal actions enforced by governmental regulatory bodies and civil or administrative actions enforced by independent regulatory bodies to prevent market-abuse offences. ${ }^{51}$ Remarkably, Shen acknowledges that the countries that used these "parallel investigation actions" have co-operatively, to a greater extent, been efficient and effective in curbing market-abuse activities.

45 Carvajal and Elliot 2009 International Monetary Fund Working Paper WP/09/168 26; also see Alexander "Insider Dealing and Market Abuse: The Financial Services and Markets Act 2000" 2001 ESRC Center for Business Research Paper 222 University of Cambridge 3-50, for a general legislative overview and discussion of related enforcement approaches employed by the United Kingdom's market abuse regime.

46 Carvajal and Elliot 2009 International Monetary Fund Working Paper WP/09/168 26; see further Brown "The Problematic and Faintly Promising Dynamics of Corporate Crime Enforcement" 2004 Ohio State Journal of Criminal Law 521 529, for a discussion on some general approaches to information gathering; and Wymeersch "Enforcement of Corporate Governance Codes" 2005 ECGI Working Paper Series in Law 46/2005 2-26.

47 Lyon and Du Plessis The Law of Insider Trading in Australia 171.

48 Lyon and Du Plessis The Law of Insider Trading in Australia 172-173.

49 Blair and Ramsay "Mandatory Corporate Disclosure Rules and Securities Regulation" in Walker, Fisse and Ramsay (eds) Securities Regulation in Australia and New Zealand (1998) 72.

50 Lyon and Du Plessis The Law of Insider Trading in Australia 173.

51 Shen 2008 Journal of Business and Securities Law 61-62.

$52 \mathrm{Ibid}$; and see related analysis by Hermann "Prompt Disclosure can Pre-empt Insider Trading" 18 August 1988 Financial Times 23. 


\section{The role and use of bounty rewards and whistle- blowing incentive measures to prevent market abuse}

Whistle-blowing occurs when an employee or another person in a contractual or non-contractual relationship with a company, reports any misconduct to outside companies or other relevant authorities for them to impose sanctions and/or to take other appropriate action against the wrongdoers. ${ }^{53}$ While, on the other hand and in this context, bounty rewards entail a financial reward payable to individuals who bona fide provide relevant information on market-abuse violations to the regulatory authorities leading to the imposition of penalties on the offenders. ${ }^{54}$ These incentive measures are employed by the regulatory authorities in some countries to encourage voluntary cooperation among all the relevant stakeholders. ${ }^{55}$

Depending on each country, whistleblowers are sometimes obliged to disclose their true identity and to provide any information relating to market abuse in good faith. In such instances, Lyon contends that the whistleblowers will be afforded some immunity from criminal or civil liability as well as losing their jobs. ${ }^{56}$ Whistleblowers are not entitled to get a reward in other countries, but they may seek compensation from the company involved for any damage suffered as a result of their whistle-blowing. ${ }^{57}$

Whistle-blowing prevents information about market-abuse violations from being concealed or remaining confidential, unknown and detrimental to the innocent investors. ${ }^{58}$ However, the main disadvantage of whistle-blowing is that the whistleblowers may hesitate to provide the information on marketabuse violations leading to more undesirable affects of such violations. ${ }^{59}$

On the one hand, depending on each country, bounty rewards may help the regulatory authorities to have more informants through anonymous calls or from employees and/or other persons who have the relevant information on market-abuse violations. ${ }^{60}$ In spite of this, the main shortcoming of bounty rewards is probability of abuse on the part of the informants, who might

53 Macey "Getting the Word Out about Fraud: A Theoretical Analysis of Whistleblowing and Insider Trading" 2007 Michigan LR 1899 1903; and Gray "Whistleblowing Protection Available under Title IX?: A Hermeneutical Divide and the Role of Courts" 2006 WM and Mary Journal of Women and Law 671, for a definitional and conceptual analysis of whistleblowing incentive measures.

54 Shen 2008 Journal of Business and Securities Law 62.

55 Brown 2004 Ohio State Journal of Criminal Law 530-531, who cites a wide range of initiatives that could be taken by the regulatory authorities to promote all persons to expose any trading irregularities within their companies or organizations.

56 This is the so-called whistleblower immunity provisions which protect them from victimization and from suffering any other reprisals. Lyon and Du Plessis The Law of Insider Trading in Australia 166.

57 Lyon and Du Plessis The Law of Insider Trading in Australia 166.

58 Macey 2007 Michigan LR 1922 for related comments and more analysis.

59 Macey 2007 Michigan LR 1928 for related comments and more analysis; and also see Stern "Complying with Sarbanes-Oxley's Whistleblower Provisions Leading Lawyers on Understanding Whistleblower Provisions, Complying with Key Regulations and Responding to Claims: Strategies for Analyzing and Responding to Sarbanes-Oxley Whistleblower Claims" 2009 ASPATORE 1 2-13.

60 Shen 2008 Journal of Business and Securities Law 62-63 for more information on the use of bounty rewards in China and the United States of America. 
come forward with false or malicious information for the "sake of gaining monetary rewards". ${ }^{61}$ Over and above, the use of bounty rewards and whistle-blowing incentive measures has not been spared of academic scholarly debates and criticism. Some academics like Shen postulates that bounty rewards are vital and key to the detection and investigation of insidertrading violations. ${ }^{62}$ Brown agrees with Shen, and adds that bounty rewards create a strong incentive for all informants to voluntarily report any marketabuse violations to the relevant authorities without the fear of incurring liability. ${ }^{63}$ Nonetheless, other scholars like Chapman and Denniss, state that bounty rewards were rejected in some countries like Australia on the basis that they "reduce the credibility of evidence put forward by the prosecution", suggesting that they are incompatible to the Australian insider-trading laws. ${ }^{64}$

With regard to whistle-blowing, Chapman and Denniss contend that whistleblowers should be compensated for any loss of earnings associated with their actions and whistle-blowing must be encouraged globally to improve the detection of market-abuse practices like insider trading. ${ }^{65}$ Nevertheless, other scholars cite a host of theoretical problems associated with whistle-blowing. In relation to this, Macey argues that whistle-blowing may "create perverse incentives for the person in possession of whistleblower information to delay revealing the information in order to complete her trading". ${ }^{66}$ Likewise, Manne advocates that whistle-blowing could provide incentives for traders to delay disclosure of relevant information until a point at which the information would otherwise be disclosed. ${ }^{67}$ The question of the degree or extent to which such delays would occur is an empirical one for which no data is available. ${ }^{68}$ Macey acknowledges this so-called timing problem but still maintains that there are significant benefits of using whistleblowing to curb market abuse that could as well outweigh the social costs and other disadvantages that are linked to them. ${ }^{69}$ Macey submits further that legal insider trading and whistle-blowing must be complementally used to prevent unlawful trading conduct. ${ }^{70}$ This submission does not, however, elaborate on how lawful insider trading can be used to prevent illegal insider trading or other related market-abuse practices without creating further controversy. The authors do not support this incentive-based justification, for

61 Lyon and Du Plessis The Law of Insider Trading in Australia 165, for similar remarks.

62 Shen 2008 Journal of Business and Securities Law 62; also see Cai "Private Securities Litigation in China: Of Prominence and Problems" 1999 Columbian Journal of Asian Law 135 , for more related comments on China's criminal investigations and prosecutions of securities violations; and Chapman and Denniss "Using Financial Incentives and Income Contingent Penalties to Detect and Punish Collusion Insider Trading" 2005 Australian and New Zealand Journal of Criminology 122 124-140.

63 Brown 2004 Ohio State Journal of Criminal Law 530-532.

64 Chapman and Denniss 2005 Australian and New Zealand Journal of Criminology 122-124, where it was stated that in some countries like the United States of America, a financial reward to report illegal conduct provides all persons with a chance to expose such conduct with a $100 \%$ certainty that they will make some profit "without risk of prosecution".

65 Chapman and Denniss 2005 Australian and New Zealand Journal of Criminology 125-126.

66 Macey 2007 Michigan LR 1928; and also "Efficient Capital Markets, Corporate Disclosure, and Enron" 2004 Cornell LR 394 404, who argues that whistle-blowing negatively affects the work of "gatekeepers such as stock market analysts".

67 Manne "The Case for Insider Trading" 2003 Wall Street Journal A14.

68 Macey 2007 Michigan LR 1928.

69 Ibid.

70 Macey 2007 Michigan LR 1927. 
permitting insider trading on the basis of "whistleblower information likelihood that such permission will decrease the actual time required for the inside information to be publicized" ${ }^{71}$ In relation to this, the authors also submit that Macey's ${ }^{72}$ submission could create more complications as regards the actual classification of information that will be regarded as "whistleblower information".

Grabosky submits that bounty rewards, whistle-blowing and other incentives may erode the effectiveness of moral rewards, hence no persons must be rewarded for carrying out the normal responsibilities required of them. ${ }^{73}$ Although these concerns could be legitimate, the authors contend that the use of bounty rewards and whistle-blowing incentives has a greater potential of creating better enforcement norms and ethics necessary to combat market-abuse activities in the global financial markets.

\section{The role and use of self-regulatory organizations to prevent market abuse}

Market-abuse regimes in many countries rely on self-regulatory organizations to enforce securities and market-abuse laws. ${ }^{74}$ According to Carvajal and Elliot, ${ }^{75}$ self-regulatory organizations are "private or semi-private organizations that carry out some regulatory functions, ranging from trade associations that set enforceable codes of conduct to stock exchanges that set and enforce trading rules to full-service regulators of the investment firm industry".

Obviously, the role of self regulatory organizations varies from country to country. In some countries self-regulatory organizations are normally responsible for regulating the stock or securities exchanges. ${ }^{76}$ Thus, selfregulatory organizations may operate surveillance systems, investigate, interrogate and execute any other action within their powers to prevent market-abuse practices. ${ }^{77}$ Carvajal and Elliot submit that in other countries self-regulatory organizations are given wider enforcement powers to supervise over the entire securities industry. ${ }^{78}$ Similarly, Cerps, Mathers and

For related comments see Macey 2007 Michigan LR 1924.

72 Ibid.

73 Grabosky "Regulation by Reward: On the Use of Incentives as Regulatory Instruments" 1995 Law and Policy 257 257-282.

74 For a further discussion on the role of the Australian Stock Exchange and the Australian Securities and Investments Commission in the enforcement of the Australian securities laws see generally Coffey "Enforcement of Continuous Disclosure in the Australian Stock Market" 2009 6-17 http://www.clta.edu.au/professional/papers/conference2009/CoffeyCLTA09.pdf (accessed 2010-10-14); and also see Chapman and Denniss 2005 Australian and New Zealand Journal of Criminology 28.

75 Carvajal and Elliot 2009 International Monetary Fund Working Paper WP/09/168 29, who cites the Financial Industry Regulatory Authority and the Japanese Securities Dealers Association as some of the examples of such self-regulatory organizations.

76 This is true of countries like South Africa, United States of America, Australia and Canada; and see further Liebman and Milhaupt 2007-2008 Columbia LR 12-16.

77 Lynch 2009 1-2 http://www.secactions.com/?p=960 (accessed 2009-05-28); for more information on the role of self-regulatory organizations see generally Cerps, Mathers and Pajuste 20069 http://www.cerge-ei.c2/pdf/gdn/RRC_100-paper-01.pdf (accessed 2010-1014).

78 Carvajal and Elliot 2009 International Monetary Fund Working Paper WP/09/168 29. 
Pajuste agree that self-regulatory organizations have a substantial role to play in the general regulation and enforcement of securities laws in most countries.

The authors submit that the role and powers of self-regulatory organizations are dependent on each country and they agree with Cerps, Mathers and Pajuste's stated above, that self-regulatory organizations have a crucial role in the general enforcement of securities (including marketabuse) laws in many countries. Likewise, Carvajal and Elliot point out that self-regulatory organizations form an integral part of the enforcement process and they must be considered in assessing the effectiveness of the securities-enforcement measures or systems as a whole. ${ }^{80}$ McNeil echoes these sentiments and submits that self-regulation can remedy problems of non-compliance so as to prevent market-abuse practices. ${ }^{81}$ Shen outlines further the crucial role played by self-regulatory organizations in some countries, in monitoring or supervising the day-to-day market-trading activity to detect and prevent market-abuse practices.

On the contrary, Puri questions whether the self-regulatory organizations will be able to engage in effective enforcement because of the commonly perceived "conflicts of interest" problem that may occur between the selfregulatory organizations and other regulatory authorities. ${ }^{83}$ Nonetheless, the authors disagree with Puri's ${ }^{84}$ submission that too much reliance on self regulatory organizations could cripple and jeopardize the consistent enforcement of the securities and/or other market-abuse laws because this statement is merely based on assumptions rather than on actual empirical evidence to support its validity.

Carvajal and Elliot reveal that self-regulatory organizations sometimes have serious weaknesses in executing their supervisory and other enforcement powers because they are given limited authority in some countries or due to the fact that they would have failed to overcome the conflicts of interest involved, especially in market-abuse disciplinary

79 See analysis by Cerps, Mathers and Pajuste "Securities Laws Enforcement in Transition Economies" $200623 \mathrm{http}: / / w w w . c e r g e-e i . c 2 / p d f / g d n / R R C \_100-p a p e r-01 . p d f$ (accessed 2010-10-14), they argue that self-regulatory organizations assist and complement the courts and other enforcement authorities to obtain or increase compliance with the securities laws on the part of all the market participants.

80 Carvajal and Elliot 2009 International Monetary Fund Working Paper WP/09/168 29.

81 See MacNeil "Enforcement of Capital Markets Regulation: The United Kingdom and Its International Markets" 2007 GovNet eJournal 1 14-15.

82 Shen 2008 Journal of Business and Securities Law 54 for further discussion on the role of stock exchanges in detecting and combating market-abuse conduct like insider trading in China and in the United States of America; also see Deakin "Economic Effects of Criminal and Civil Sanctions in the Context of Company Law" 2000 ESRC Centre for Business Research Paper, University of Cambridge 5, for related comments on the role of selfregulatory organisations; Coffee 2009 Columbia University Law School Memorandum Paper $03 / 09 / 0911$, for a testimony and discussion on the role and desirability of self-regulatory organizations; and Liebman and Milhaupt 2007-2008 Columbia LR 12-16, for further analysis of the role of self-regulatory organizations.

83 Puri "Enforcement Effectiveness in the Canadian Capital Markets" 2005 Capital Markets Institute Paper, York University 5, where it was stated that too much enforcement activity by the government, regulatory bodies and the self-regulatory organizations may create conflicts of interest problems that affects the effectiveness of self-regulation adversely in general.

84 Puri 2005 Capital Markets Institute Paper, York University 7. 
actions. ${ }^{85}$ Despite these potential disadvantages, the authors contend that the role of self-regulatory organizations must be cherished and encouraged in all the countries to improve the enforcement of market-abuse laws.

\section{CONCLUDING REMARKS}

This article has analysed five measures that are commonly employed to deal primarily with the surveillance, detection and investigation of market-abuse activities globally, namely: regulatory bodies, surveillance and detection measures, investigation- and information-gathering measures, bounty rewards and whistle-blowing incentive measures and self-regulatory organizations. The significant advantages and disadvantages of each of these approaches were also briefly outlined in order to bring some general insight to the reader on how such approaches might have been utilized to combat market abuse in different jurisdictions. In relation to this, a similar analysis of anti-market abuse measures that primarily deal with the enforcement of the market-abuse prohibition globally, namely: criminal measures, civil measures, private rights of action and class actions, arbitration and alternative dispute-resolution measures, administrative sanctions and Chinese Walls were undertaken in the first article. It was noted that each of the anti-market abuse-enforcement approaches discussed in both the first and second article has different strengths and weaknesses. Consequently, it is submitted that these enforcement approaches must be used cooperatively to prevent market-abuse practices globally. It is further submitted that relying on one or a few of these antimarket-abuse enforcement approaches might be too narrow and less effective. It was also noted that there has not been much legal research that specifically focused on the role and use of general anti-market abuseenforcement approaches to combat market abuse. Accordingly, it is submitted that lawyers and/or academics should consider embarking to a greater extent on legal research pertaining to such approaches to increase awareness and enforcement on the part of the relevant stakeholders. It is further submitted that the regulatory authorities should have, and promote, a greater understanding of the role and use of several anti-market abuseenforcement approaches in order to increase the successful enforcement of market-abuse laws in any jurisdiction.

These sentiments and the need for robust enforcement measures were also underscored in the following quotation:

"Having the enforcement shotgun behind the door is important for every regulator, even in industries where non-compliance is the exception".

\footnotetext{
85 Carvajal and Elliot 2009 International Monetary Fund Working Paper WP/09/168 29. Also see Barton The Implementation of the EU Market Abuse Directive under UK Law - The Challenges Ahead (Dissertation, University of Warwick, 2004) 32-44. See Chapter Four of this dissertation for further discussion on the role of the Financial Services Authority and the challenges it faces when implementing the European Union Market Abuse Directive.

86 Van Deventer 2009 FSB Bulletin 3.
} 